\title{
Feminist legal biography: a model for all legal life stories
}

Article

Accepted Version

Auchmuty, R. and Rackley, E. (2020) Feminist legal biography: a model for all legal life stories. Journal of Legal History, 41 (2). pp. 186-211. ISSN 1744-0564 doi:

https://doi.org/10.1080/01440365.2020.1783604 Available at https://centaur.reading.ac.uk/91294/

It is advisable to refer to the publisher's version if you intend to cite from the work. See Guidance on citing.

To link to this article DOI: http://dx.doi.org/10.1080/01440365.2020.1783604

Publisher: Taylor \& Francis

All outputs in CentAUR are protected by Intellectual Property Rights law, including copyright law. Copyright and IPR is retained by the creators or other copyright holders. Terms and conditions for use of this material are defined in the End User Agreement.

\section{www.reading.ac.uk/centaur}

\section{CentAUR}

Central Archive at the University of Reading

Reading's research outputs online 


\title{
Feminist Legal Biography: A Model for All Legal Life Stories
}

\author{
Rosemary Auchmuty and Erika Rackley \\ CONTACT Rosemary Auchmuty r.auchmuty@reading.ac.uk University of Reading \\ School of Law, Reading, UK
}

\begin{abstract}
Legal biography remains, with some exceptions, strongly influenced by Victorian biographical models, with a focus on 'great' men (since women could not become lawyers before 1920, and there have been few 'great' women lawyers) and their public achievements and contributions to law, and with little attention given to their private lives or their attitudes to women's subordination in law. Feminist legal historians have widened the net to include women pioneers working in and with law before 1920. But feminist legal biography is not just about uncovering the lost lives of women; rather, it focuses on gender - the relationship between the sexes - and recognizes that biographies of men require consideration of the ways in which men maintained their dominant position in law and society, as much by the private support of women at home as by excluding and marginalizing women professionally. As for biographies of women, recent enthusiasm to recover their stories has suffered from a tendency to mould them into heroines or role models, again on the Victorian model. Feminist legal biographers of women need to avoid the perils of over-identification with their subjects (manifested by anachronistic familiarity and historical inaccuracy) and the siren call of anecdote and myth.
\end{abstract}

\section{Introduction}

Readers of this journal may well ask themselves: What is an article on feminist legal biography doing in a collection largely focused on Victorian and Edwardian legal biographies? What relevance could it possibly have to studies of legal professionals in an era when women could not even be members of the profession? This article has two main aims and, in turn, two audiences. First, it seeks to demonstrate to the traditional legal biographer, who can see little place for women in a biographical study from the Victorian or Edwardian era, that a consideration of women themselves and of men's relationships to them is not only relevant but essential to the re-creation of a subject's life in any era. Second, it addresses the 
current surge of interest in uncovering the stories of women in law, prompted on the one hand by a desire to celebrate the centenaries of women's admission to the vote and the legislature in 1918 and to the legal profession in $1919,{ }^{1}$ and on the other by the influence of feminist scholarship rather belatedly reaching the discipline of law and the sub-discipline of legal history. $^{2}$

We begin by considering the ongoing impact of Victorian and Edwardian biography on traditional legal biographies, and the relationship between law and history in today's discipline of legal biography. We go on to explore the rationale and methodology of feminist legal biography, outlining three principles - that women's issues belong in legal history, that the personal matters, and that heroines do not help - and three pitfalls to avoid. Feminist legal biography, we conclude, means not just including the occasional woman who made her name in a man's world, but acknowledging the significance of all women who facilitated men's domination of that world for so long. In so doing it produces a range of new, more diverse and inclusive life stories and has the potential to transform legal history.

\section{Victorian and Edwardian Biography}

In the nineteenth century, biographical writing was one of the mechanisms by which Britain asserted its dominant place in the world as a civilizing force as much as a political and economic power. National excellence was celebrated in studies of 'politicians and statesmen, military or naval heroes, churchmen, writers, and teachers'. ${ }^{3}$ The National Portrait Gallery, founded in 1856, illustrated this excellence in pictorial form: the visitor to the Victorian galleries today sees portraits (including, these days, a reasonable sprinkling of women) posed formally, face to viewer, commanding their environment. Almost thirty years later, the

\footnotetext{
${ }^{1}$ As exemplified by a variety of initiatives, such as the Women's Legal Landmarks project (Erika Rackley and Rosemary Auchmuty, eds., Women's Legal Landmarks: Celebrating the History of Women and Law in the UK and Ireland, Oxford, 2019); the First 100 Years project: https://first100years.org.uk; and Judith Bourne's symposia on the 'First Women Lawyers in Great Britain and the Empire' (Women's History Review, 2020, forthcoming).

${ }^{2}$ Rosemary Auchmuty 'Recovering Lost Lives: Researching Women in Legal History', 42 Journal of Law and Society (2015), 34; Erika Rackley and Rosemary Auchmuty 'The Case for Feminist Legal History', Oxford Journal of Legal Studies, forthcoming.

${ }^{3}$ Hermione Lee, Biography: A Very Short Introduction, Oxford, 2009, 63.
} 
Dictionary of National Biography was established as a compendium of the great and good of British history, of which fewer than four per cent were women. ${ }^{4}$ These monuments to national pride focused on professional achievements, telling a tale that, in spite of challenges and setbacks, led 'upwards and onwards', ${ }^{5}$ like the Victorian age itself.

As biography was perceived to be a celebration of public achievement, only those who had contributed to British public life were included and only those public contributions were discussed. Little was said about other aspects of a person's life: 'Childhood problems, domestic privacies, affairs and scandals were played down', notes Hermione Lee. ${ }^{6}$ This presentation marked a reaction against the more open approach of the eighteenth century, during which Dr Johnson had observed that it was in the home that 'a man shrinks to his natural dimensions', and that more knowledge of his character might be gleaned from 'a short conversation with one of his servants, than from a formal and studied narrative'. 'Within a generation', Nigel Hamilton observes, 'the mood in Victorian Europe and America had changed': the personal, private and domestic disappeared, and Victorian biography 'exuded panegyric - spun out at vast length, devoted to public lives, and restricted to males' 8

The reason for the shift was clear. Historically, one of the many purposes of biography (and Victorian biography in particular) was to inspire admiration and emulation. For Victorian men, this representation required a focus on a subject's public life. Such a focus permitted a veil to be drawn over any aspects of his private life that might convey a discordant message. Omissions were easily justified by the Victorian ideology of separate spheres: the notion that the public sphere was men's preserve, while the private belonged to women and so was out of place in a study of a man's life and work. Meanwhile the intersection of the separate spheres ideology with the sexual double standard allowed society to ignore a public man's behaviour towards the women in his life, who might include his wife and his mistresses, and ensured that it could continue uncensored and unrecorded.

It was in studies of women that the twin purposes of Victorian biography - the celebration of Britain's great civilization and the presentation of role models for readers to

\footnotetext{
${ }^{4}$ Ibid., 67.

${ }^{5}$ Ibid., 63.

${ }^{6}$ Ibid.

${ }^{7}$ The Rambler 60 (1750), quoted in Nigel Hamilton, How to Do Biography: A Primer, Cambridge, MA, 2008, 12.

${ }^{8}$ Hamilton, How to Do Biography, 15, 17.
} 
admire and follow - came together most obviously. The huge transformations in women's social, educational, professional and, especially, legal position that took place in the second half of the nineteenth century could be (and were) ascribed to that same process of civilization, rather than to very active women's movement that fought for them. As A R Cleveland wrote in 1896, 'it is very questionable whether woman has ever gained any great concessions by direct agitation ... If, then, women themselves did not bring about these alterations, to whom or to what are we to attribute them? We think, unquestionably, to the progress of civilization'?

Women's lives could be crafted more easily than men's into the role model mould because their allocated role was as moral guardians and educators of the young. There are dozens of Victorian and Edwardian biographies of Victorian and Edwardian women, all purporting to recognize their contribution to public life, while at the same time providing blueprints for what girls might aspire to and how women should live.

Biographers of women faced a different task from that faced by biographers of men. They could not write of women in public life without considering the private sphere, if only to explain why and how their subject had stepped outside of it. Mrs Gaskell set the tone with The Life of Charlotte Brontë, published in 1857. ${ }^{10}$ This focused sympathetically on the personal and domestic context in which Brontë's novels were produced, while also defending her against the accusations of unwomanliness her writing had attracted thanks both to its engagement with purportedly dangerous topics (as Gaskell had found a few years earlier when she published Ruth, ${ }^{11}$ a novel about a 'fallen woman'), and to her temerity in entering the public sphere by publishing her work at all. Other biographies of women writers capitalized on the moral or Christian messages purveyed by their books, especially if directed at young people. ${ }^{12}$ Anyone in a charitable or caring role was acceptable as a subject for biography, and studies of women prominent in philanthropic and mission work formed a large group whose readership could be assured through the Sunday school prize market, and

\footnotetext{
${ }^{9}$ A.R. Cleveland, Woman Under the English Law, London, 1896, 255, 299.

${ }^{10}$ Mrs Gaskell, The Life of Charlotte Brontë, London, 1857.

${ }^{11}$ Mrs Gaskell, Ruth, London, 1853.

12 See, e.g., Agnes Giberne's A Lady of England, London, 1895 - a biography of Charlotte Maria Tucker, 'A.L.O.E.', author of allegorical tales - and Christabel Coleridge's Charlotte Mary Yonge: Her life and letters, London, 1903.
} 
whose purpose was self-evident in an era when not all genteel women married but there was little else for them to do. ${ }^{13}$

One notable exception to this focus on morality and Christian values can be found in the biographies of the pioneering headmistresses of the new academic schools for girls and principals of women's colleges in which the authors use the cover of teaching (a role traditionally associated with women) to make a feminist point about equality of status and treatment, memorializing professional women whose lives parallelled those of men. ${ }^{14}$ Jenny Uglow notes that these biographies, in contrast to those of professional men, often revealed 'the added energy so often required to combine the roles of career woman or campaigner and mother, or to face the ridicule and hostility which so often greeted their abandonment of traditional duties'. ${ }^{15}$

Women's lives were most commonly presented in collections with titles such as Four Noble Women and their Work, Noble Work by Noble Women, Women Who Have Worked and Won, Women of Worth, ${ }^{16}$ Twelve Notable Good Women of the XIXth Century, ${ }^{17}$ and Noble Women of Our Time. ${ }^{18}$ While the titles are revealing of the intended market for these volumes, they often concealed a more radical purpose: some of these 'noble' and 'good' women were, in fact, feminist reformers. ${ }^{19}$ These more radical figures functioned to expand

${ }^{13}$ See, e.g., Clara M. S. Lowe's God's Answers: A Record of Miss Annie McPherson's Work, London, 1882 - she arranged emigration for 'pauper children'; Frances Martin's Elizabeth Gilbert and her Work for the Blind, London, 1891; and Rosa M. Barrett's Ellice Hopkins: A Memoir, London, 1907 - she promoted purity.

${ }^{14}$ See, e.g., Elizabeth Raikes, Dorothea Beale of Cheltenham, London, 1908; Annie E. Ridley, Frances Mary Buss, London, 1895; Blanche Athena Clough, A Memoir of Anne Jemima Clough, London, 1897.

15 Jennifer S Uglow, ed., The Macmillan Dictionary of Women's Biography, London, 1984, viii.

16 All by Jennie Chappell and published in London in 1898, 1900, 1904 and 1908 respectively.

${ }^{17}$ Rosa Nouchette Carey, Twelve Notable Good Women of the XIXth Century, London, 1899.

${ }^{18}$ Frederick Douglas How, Noble Women of Our Time, London, 1901.

19 On ways in which Victorian biographies of women could be read transgressively, see Alison Booth, How to Make It as a Woman: Collective Biographical History from Victoria to 
readers' horizons in ways not always evident to those who prescribed women's role. Frances Power Cobbe, for example, whose campaigns encompassed the promotion of women's higher education, married women's property reform, remedies for women escaping domestic violence, and animal rights, is positioned alongside more conventional exemplars of nobility like 'Sister Dora' (Dorothy Pattison, a nurse) and Agnes Weston, who ministered to soldiers and sailors. ${ }^{20}$ Florence Nightingale had her multiple recognitions in these collections, of course, and the framing of the life of the founder of the nursing profession as the 'lady of the lamp', rather than the astute political strategist that she was, is largely due to Victorian efforts to cast her story into a suitable feminine mould. ${ }^{21}$

\section{A New Approach to Biography}

Reaction against Victorian and Edwardian biography is said to date from the publication in 1918 of Lytton Strachey's Eminent Victorians. ${ }^{22}$ His study of four public figures (among them, one woman, Florence Nightingale) set out to debunk the Victorian models of propriety and heroism, and to show them to be motivated not so much by national pride but by private anxieties and personal traumas, but also to lay the blame for a long, bloody war at the feet of

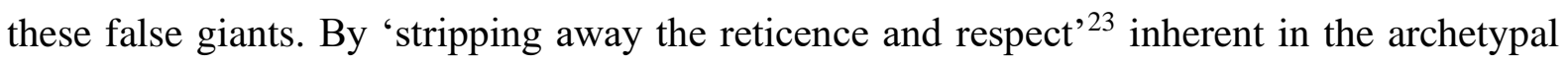
Victorian and Edwardian biography, this began a process of democratizing the genre. There followed a gradual - very gradual - movement towards greater exploration of the personal lives that lay behind the public personas of biography. A growing attraction to psychology, a greater scepticism about the nature of fame, and vastly increased availability of information about people all fed into a different approach to biographical writing.

the Present, Chicago, 2004, and Juliette Atkinson, Victorian Biography Reconsidered, Oxford, 2010, ch. 5.

${ }^{20}$ In Jeanie Douglas Cochrane, Peerless Women: A Book for Girls, London and Glasgow, 1905; Chappell, Four Noble Women and their Work, Women of Worth; Carey, Twelve Notable Good Women.

${ }^{21}$ See, e.g., Lizzie Alldridge, Florence Nightingale, F. R. Havergal, Catherine Marsh etc, London, 1885.

${ }^{22}$ Lytton Strachey, Eminent Victorians, London, 1918.

${ }^{23}$ Emily Bowles and Emma Butcher, '(Re)Negotiating Victorian Biography: Subversion and appropriation in late Victorian and twentieth-century life writing', 10 Peer English (2015), 6. 
Today the Victorian model is no longer the standard format for mainstream biography. While a contribution to public life may be the motivation for a biographical study, '[t]he emphasis', Lee suggests, 'has shifted in the relative coverage of public achievements and domestic behaviour'. ${ }^{24}$ Modern readers are no longer solely interested in the public life of a subject; they want to know something of his or her private life, too. Today's readers expect to be told that a notable figure entertained racist or fascist views, was friendly with known pimps or paedophiles (or was one himself), or abused his wife - not for voyeuristic reasons, but because there is a recognition that those attitudes, relationships or behaviour must have some effect on a person's public life - or at least that a potential effect must be considered.

And yet Victorian biographies continue to set the tone and provide a model for legal biography. This should not surprise us, given how similar to Victorian conceptions of historical development is the legal discipline's methodology and view of itself. Law, like Victorian society, has long clung to a division between public and private life and steered clear of the latter. And legal history in particular, which emerged as a sub-discipline in the late Victorian period, produced texts that were 'sneakily Whiggish' in tone until well into the twentieth century. ${ }^{25}$ Law continues to present itself as a progression towards justice and equality and celebrates the winners in the doctrinal war - the statute that passed, the principle that succeeded - excluding 'irrelevant' detail that does not fit the chosen legal narrative, just as Victorian biography eschewed discussion of a subject's personal life. The result is that, in many legal biographies today, men are still portrayed largely in terms of their contribution to the public sphere of legal reform and/or development of legal doctrine, while women may be judged, if not in terms of 'noble' or 'good', certainly in terms of their work for humanity or social reform or the help they offered to women coming after them.

\section{Legal Biography: Law and History}

Legal biography draws on two disciplines, law and history. How these two components interrelate - or even what they stand for - is not always agreed. Indeed, one of the problems we faced in writing this article was where to start. It soon became clear that some things that are axiomatic to the seasoned legal biographer are not always so to the feminist legal scholar

\footnotetext{
${ }^{24}$ Lee, Biography, 8.

${ }^{25}$ Ian Ward, English Legal Histories, London, 2019, 11.
} 
- and vice versa. The differences come down to definition: what is the role of history in legal biography, and what is encompassed by legal?

\section{The role and importance of historical context}

Doing justice to the legal past, David Sugarman explains, 'requires us to excavate a much wider range of subject-matter than that usually imbibed by lawyers' legal history [our emphasis]'. ${ }^{26}$ While lawyers have 'always appreciated the importance of history', ${ }^{27}$ they have not always been good at doing it. The need to locate the law and legal actors in their historical setting, in all its 'social, economic and political dimensions', ${ }^{28}$ and to undertake indepth research into secondary sources written by historians as well as non-legal records, runs counter to the training of many legal scholars, who are not only not familiar with this material, but have been trained to disregard it - to rely only on strictly legal sources. We found that many contributors to the Women's Legal Landmarks project were taken aback when they discovered how much historical writing had already been done on the issues relevant to their landmark event or life, much of it only available in printed form rather than online. Legal scholars lacking specialist training tend, moreover, to focus on law as it is now; on our undergraduate degrees its development is usually dealt with superficially in a 'then' and 'now' way and, for younger scholars in particular, 'then' may simply be any time between the Victorian age and the millennium, with the specific features of the period lost in a patriarchal blur.

The tendency to focus on the legal to the exclusion of the social also characterized much twentieth-century legal history writing. Legal developments may have been meticulously chronicled but their non-legal causes and effects less so. Ian Ward's wry assessment of John Baker's Introduction to English Legal History ${ }^{29}$ - 'full of cases, statutes and principles. But not much poetry' - provided part of the impetus for his own explorations

\footnotetext{
${ }^{26}$ David Sugarman, 'The Legal Boundaries of Liberty: Dicey, Liberalism and Legal Science', 46 Modern Law Review (1983), 102 at 104.

${ }^{27}$ Ward, English Legal Histories, 10.

28 Chantal Stebbings, 'Benefits and Barriers: the making of Victorian legal history' in Anthony Musson and Chantal Stebbings, eds., Making Legal History: Approaches and Methodology, Cambridge, 2012, 86.

${ }^{29}$ John Baker, An Introduction to English Legal History, Oxford, 4th ed. 2000.
} 
of the stories and contemporary backgrounds of his chosen legal events. ${ }^{30}$ Likewise, in a biography of William Blackstone, Wilfrid Prest complained of the unwillingness of legal biographers to set their subjects in a wider context than the world of law:

Over the past quarter-century, historians have shown greater willingness to come to terms with the law's various cultural, economic, political, and social dimensions. But Blackstone still tends to be relegated to 'legal history', conceived of as a marginal sub-discipline dominated by antiquarian lawyers and legal academics. ${ }^{31}$

This failure to recreate historical context in the lives of legal women in the US was recognized by Norma Basch thirty-five years ago:

The compelling challenge confronting scholars today, I think, is to devise ways to close this seemingly unbridgeable gap between the purely historical and the purely legal that is characteristic of so much work in the field. For feminist legal scholars trained in the discipline of law, this means drawing on the abundant secondary sources in women's history so as to be able to invest their work with great contextual breadth and more chronological precision. ${ }^{32}$

Today, of course, there are many excellent examples of legal histories set in social context. These include the work of David Sugarman and Linda Mulcahy ${ }^{33}$ in the UK and, among feminist legal scholars, Anne Logan ${ }^{34}$ in the UK, Constance Backhouse ${ }^{35}$ and Mary

30 Ward, English Legal Histories, 11.

${ }^{31}$ Wilfrid Prest, William Blackstone: Law and Letters in the Eighteenth Century, Oxford, $2008,9$.

${ }^{32}$ Norma Basch, 'The Emerging Legal History of Women in the United States: Property, Divorce, and the Constitution' 12 Signs (1986), 97 at 116.

${ }^{33}$ See, e.g., Linda Mulcahy and David Sugarman, eds., Legal Life Writing: Marginalised life subjects and sources, Oxford, 2015.

34 See, e.g., Anne Logan, Feminism and Criminal Justice: A Historical Perspective, Basingstoke, 2008; The Politics of Penal Reform: Margery Fry and the Howard League, Oxford, 2018.

${ }^{35}$ See, e.g., Constance Backhouse, Challenging Times: Women's Movements in Canada and the United States, Montreal, 1992; Colour-Coded: A legal history of racism in Canada, 1900-1950, Toronto, 1999. 
Jane Mossman ${ }^{36}$ in Canada and Barbara Babcock ${ }^{37}$ and Felice Batlan ${ }^{38}$ in the United States. It is not to these authors that this article is addressed; rather, their work should serve as models for what we are trying to describe. That a cavalier approach to historical background still exists, however, is evident when we look at the many potted biographies of 'trailblazing' women lawyers which have recently appeared online and in edited collections. Often no more than compilations of public details, with some anecdotes thrown in, these 'life stories' lack adequate consideration of the social norms and practices of the time. Much is assumed - the sexual division of labour, for example - but its specific features in any given time, or their ramifications, are rarely described, let alone explored. Nor is anything made of the fact that the law itself at best permitted and at worst encouraged husbands to keep their wives out of the workplace, as Susan Atkins and Brenda Hale's study of Women and the Law in the mid1980s so eloquently demonstrated. ${ }^{39}$

Context is important for another reason. It is a truism that history is a dialogue between past and present, but what this really means is that the history we write today will be different from a history of the same events written in 1900 or 1950. That is partly because the experiences of years subsequent to the events alter our understanding of their significance and partly because the concerns of today cause us to focus on certain aspects of the past and to interpret them in ways that reflect our modern preoccupations. Again, this is a particular trap for the legal scholar accustomed to viewing the development of law from the perspective of the present. The task of the biographer is to recreate the past as our subject might have experienced it, and that means trying to get into the mind-set of the past, which you cannot do if you do not imagine it to be any different from your own.

\section{The subjects and non-subjects of legal biography}

${ }^{36}$ See, e.g., Mary Jane Mossman, The First Women Lawyers: A comparative study of gender, law and the legal professions, Oxford, 2006.

${ }^{37}$ See, e.g., Barbara Babcock, Woman Lawyer: The trials of Clara Foltz, Stanford, 2011.

${ }^{38}$ See, e.g., Felice Batlan, Women and Justice for the Poor: A history of legal aid, 18631945, Cambridge, 2015.

${ }^{39}$ Susan Atkins and Brenda Hoggett, Women and the Law, Oxford, 1984; reissued London, 2018, available at https://humanities-digitallibrary.org/index.php/hdl/catalog/book/atkins_hoggett), esp. ch. 6. 
If history is one important component of legal biography, law is the other. A further difference between traditional legal biographers and feminist legal scholars is their understanding of the word 'legal' in this context. Traditionally, legal biography has meant biographies of lawyers - that is, members of the legal profession and legal academy. Feminist legal scholars have never limited their definition to qualified lawyers, not least because to do so would mean that there would be no legal biographies of British women before 1919, when women were formally admitted into the profession.

English legal history has - almost in its entirety - been written as history of 'great men'. ${ }^{40}$ Sometimes literally: William Holdsworth's book, Some Makers of English Law, first published in 1938, credits almost 700 years of English legal history to the 'labour' of twentyfour men. ${ }^{41}$ Michael Birks's history of the solicitors' profession, Gentlemen of the Law, contains no index reference for 'women' and just two to relating to 'solicitors, women'. ${ }^{42}$ Legal biography has correspondingly been an almost exclusively masculine exercise. Since women active in law before 1919 have not counted, and their participation after that date has been limited, no one feels the need to explain their absence. It is assumed that there are very, very few legal biographies of British women because have been very few outstanding women lawyers and judges. ${ }^{43}$

Starting in the United States and Canada, feminist legal scholars set out to challenge this exclusion. Because their research focused on the campaigns for entry into the profession, they necessarily studied the lives of women active in those campaigns, many of whom never actually qualified as lawyers. When Mary Jane Mossman came to write her ground-breaking study, The First Women Lawyers, she adopted a wide-ranging definition of the word 'lawyer'

${ }^{40}$ Felice Batlan, 'Legal History and the Politics of Inclusion', 26 Journal of Women's History (2014), 155.

${ }^{41}$ William Holdsworth, Some Makers of English Law, 1938, repr. Cambridge, 2009. W. R. Cornish and G. de N. Clark's Law and Society in England 1750-1950, London, 1989, runs to 700 pages and has no index entry for 'women', though two for 'wife', while Frederic W. Maitland and Francis C. Montague's A Sketch of English Legal History, London, 1915, has neither.

${ }^{42}$ Michael Birks, Gentlemen of the Law, London, 1960.

${ }^{43}$ But see Judith Bourne, Helena Normanton and the Opening of the Bar to Women, London, 2016; Hilary Heilbron, Rose Heilbron: The story of England's first woman Queen's Counsel and Judge, Oxford, 2012. 
to encompass not only those women who gained formal admission, but also those who were engaged in legal work though still barred, on the ground that this enabled her to explore the opposition to women's claims in the different jurisdictions. ${ }^{44}$ This led her to choose Eliza Orme for her UK case study, a woman who ran her own legal practice in Victorian Britain (with legal men to provide the official imprimatur) but who never formally qualified as a lawyer. ${ }^{45}$ In truth, though, since all the other countries Mossman considered had admitted women by 1900 (with the exception of India which was still under British rule), to keep the comparison contemporaneous she had to include unqualified women like Orme, or leave Britain out. Nevertheless, it is thanks to the work of Mossman, drawing on the original research of Leslie Howsam, ${ }^{46}$ that Orme quickly became better known to legal historians than most of the actual first qualified lawyers.

Since then we have seen a tide of work on pioneering women in law: Rosemary Auchmuty's work on early women law students ${ }^{47}$ and on Gwyneth Bebb, who gave her name to the case, Bebb v Law Society [1914] 1 Ch. $286 ;{ }^{48}$ multiple entries in the Oxford Dictionary of National Biography (which had set itself the task of increasing the representation of women and other marginalized groups); ${ }^{49}$ the First 100 Years project, whose podcasts

\footnotetext{
${ }^{44}$ Mossman, The First Women Lawyers, 9.

${ }^{45}$ She became, however, Britain's first woman law graduate with a University of London external LL.B gained in 1888.
}

${ }^{46}$ Leslie Howsam, "'Sound-Minded Women": Eliza Orme and the study and practice of law in late-Victorian England', 15 Atlantis (1989), 44; Leslie Howsam, 'Eliza Orme (18481937)', Oxford Dictionary of National Biography, https://doi.org/10.1093/ref:odnb/37825.

${ }^{47}$ Rosemary Auchmuty, 'Early Women Law Students at Cambridge and Oxford', 29 Journal of Legal History (2008), 63; Rosemary Auchmuty 'Feminists as Stakeholders in the Law School' in Fiona Cownie, ed., Stakeholders in the Law School, Oxford, 2010, 35-64.

${ }^{48}$ Rosemary Auchmuty, 'Whatever happened to Miss Bebb? Bebb v The Law Society and women's legal history', 31 Legal Studies (2011), 175. See also Rosemary Auchmuty, 'Bebb [Married name Thomson], Gwyneth Marjory (1889-1921)', Oxford Dictionary of National Biography, https://doi.org/10.1093/ref:odnb/101944.

49 Elizabeth Baigent, Charlotte Brewer and Vivienne Larminie, 'Gender in the Archive: Women in the Oxford Dictionary of National Biography and the Oxford English Dictionary', 30 Archives (2005), 13. There are currently thirty-four entries categorized as 'female' and either 'lawyer', 'barrister' or 'solicitor'. 
featuring scholars working in the field have been followed by a book covering the progress of women lawyers and judges since 1919; ${ }^{50}$ Judith Bourne's symposia on the first women lawyers in Great Britain and the empire, ${ }^{51}$ as well as a number individual projects - by academics and independent historians - dedicated to recovering and recording the lives of pioneering women in law, past and present. ${ }^{52}$ Much of this work has been picked up and retold in popular form, to form part of the general knowledge (such as it is) of women's legal history. Bebb's story, for example, has been re-imagined in Alex Giles's play, The Disappearance of Miss Bebb (in which Lady Hale performed the part of a feminist activist at its first performance in London) ${ }^{53}$ and Jane Robinson's Ladies Can't Climb Ladders, which focuses on the lives of pioneering women forging careers in medicine, law, academia, architecture, engineering and the church. ${ }^{54}$ Catchy precis of the lives of Bodichon, Orme, Normanton, Heilbron and other women appear in the children's book History Rocks! With Guy Fox: Women in Law. ${ }^{55}$

Some of these women became lawyers (and judges); many did not. If, instead of focusing on those with a particular job title, we ask 'if only men could be lawyers and judges, what were the women doing, and why?', it becomes clear that women have been 'in' law for centuries. ${ }^{56}$ As the example of Eliza Orme shows, women were de facto lawyers doing legal work in Victorian and Edwardian England, although barred by reason of sex from formally entering the profession. Women were able to study law at Oxford from 1875 and Cambridge

\footnotetext{
${ }^{50}$ Lucinda Acland and Katie Broomfield, First 100 Years of Women in Law, London, 2019.

${ }^{51}$ Judith Bourne, ed., First Women Lawyers in Great Britain and the Empire Vol. 1, London, 2016 and special issue of Women's History Review, forthcoming 2020.

52 See, e.g., Fiona Cownie, 'The United Kingdom's First Woman Law Professor: An Archerian Analysis', 42 Journal of Law and Society (2015), 127; Liz Goldthrope, 'Averil Deverell (First Woman to Practise as a Barrister in Ireland and the (then) United Kingdom, 1921 ' in Rackley and Auchmuty, Women's Legal Landmarks, 175; Judith Bourne, Helena Normanton and the Opening of the Bar to Women, London, 2016.

53 Alex Giles, The Disappearance of Miss Bebb: https://www.thekalishertrust.org/theatreevents/past-productions/disappearance-miss-bebb-alex-giles/

${ }^{54}$ Jane Robinson, Ladies Can't Climb Ladders, London, 2020.

${ }^{55}$ Guy Fox, History Rocks: Women in Law, London, 2019.

56 As documented by first-wave feminist historians like Charlotte Carmichael Stopes, British Freewomen: Their Historical Privilege, London, 1894, 35.
} 
from 1889 and some would have become lawyers had the professional examinations been open to them. ${ }^{57}$ Many took part in the movement for admission (Christabel Pankhurst is perhaps the best-known example; she obtained a first-class honours degree at Manchester in 1906 after her application to join the bar was turned down in 1903). ${ }^{58}$ Others used their legal knowledge in the fields of work they moved into. Gwyneth Bebb, for instance, conducted prosecutions for the board of trade and, during the first world war, for the ministry of food. ${ }^{59}$ The inclusion of such pioneers within the field of legal biography is not only legitimate but vital: to do otherwise would be to consign them to history twice, ignored by their contemporaries and by ours.

And what of those women who had no connection with law as a topic of study or profession, but who conducted feminist campaigns that focused squarely on law? - women like Barbara Leigh Bodichon, whose Brief Summary in Plain Language of the Most Important Laws Concerning Women laid the groundwork for other women engaging with law reform. ${ }^{60}$ They are women 'in law' too. For many, the first spur to feminist action was observing law's unjust workings in practice. ${ }^{61}$ While some experienced this first hand - as did Caroline Norton who led a successful crusade to amend the child custody laws ${ }^{62}$ - others witnessed its impact on others - as did Frances Power Cobbe when she took up the cause of abused wives that led to the passing of the Matrimonial Causes Act $1878 .{ }^{63}$ Because the

57 See Auchmuty, 'Early Women Law Students at Cambridge and Oxford'.

58 Auchmuty, 'Women as Stakeholders in the Law School', 42.

${ }^{59}$ Auchmuty, 'Whatever Happened to Miss Bebb?', 218.

${ }^{60}$ See Joanne Conaghan, 'A Brief Summary of the Most Important Laws Concerning Women, Barbara Leigh Smith Bodichon, 1854', in Rackley and Auchmuty, Women's Legal Landmarks, 55.

61 The same phenomenon can be observed with respect to second-wave feminists, many of whom (including family law barrister and defender of Greenham Common women Elizabeth Woodcraft, for example) studied law as a result of campaigning around legal issues concerning women. See further Auchmuty, 'Stakeholders in the Law School'.

62 Caroline Norton, English Laws for Women in the Nineteenth Century, London, 1854; Barbara Caine, English Feminism, 1780-1980, Oxford, 1997.

${ }^{63}$ Frances Power Cobbe, 'Wife Torture in England', 23 Contemporary Review (1878), 56; Barbara Caine, Victorian Feminists, Oxford, 1992, 103; Susan Hamilton, Frances Power Cobbe and Victorian Feminism, Basingstoke, 2006. 
methods women used - the only ones available to them - were speeches and published writings, we know just how much they understood about the law. ${ }^{64}$ Bodichon's successors did not stop at merely presenting the letter of the law. Rather, they contested the complacent assertions of its kindness to women, ${ }^{65}$ and set it in its social and economic context, drawing attention to the ways it was enforced (or not) and demonstrating its unjust effect - much as feminist legal scholars have been doing more recently. And they proposed reforms, many of which were taken forward by male supporters in parliament or the courts.

When one considers just how many of the first-wave campaigns were legal ones - as well as those already mentioned, the extension of the franchise at every level, campaigns around the age of consent and the double standard, Lady Rhondda's efforts to open the house of lords to women, ${ }^{66}$ Josephine Butler's work to repeal the Contagious Diseases Acts, ${ }^{67}$ Cicely Hamilton's attack on the marriage laws ${ }^{68}$ - we might legitimately be surprised that so little evidence of their efforts appears in our standard legal histories. Thanks to the advent of women's studies in the 1970s and subsequent developments in feminist history-writing, we do, however, have biographical studies of many of the major Victorian feminists who were involved in trying to change the laws affecting women. ${ }^{69}$ Some of these biographies focus

${ }^{64}$ On this point see Ian Ward's fascinating discussion in Law and the Brontës, London, 2012, and Ellen Wood's East Lynne in 'Carlyle v Carlyle: A Criminal Conversation' 65 Current Legal Problems (2012), 119.

${ }^{65}$ E.g. Blackstone's famous remark that 'even the disabilities which the wife lies under are for the most part intended for her protection and benefit: so great a favourite is the female sex of the laws of England'. William Blackstone, Commentaries on the Laws of England, Vol 1, Oxford, 1765, 442. For an early feminist critique, see Mary R. Beard, Women as Force in History, New York, 1946, 78-95.

${ }^{66}$ Viscountess Rhondda's Claim [1922] 2 AC 339.

${ }^{67}$ Josephine Butler, Personal Reminiscences of a Great Campaign, London, 1896.

${ }^{68}$ Cicely Hamilton, Marriage as a Trade, London, 1909; repr. London, 1981.

${ }^{69}$ E.g. Jane Jordan, Josephine Butler, London, 2001; Angela V. John, Turning the Tide: The Life of Lady Rhondda, London, 2014; Lis Whitelaw, The Life and Rebellious Times of Cicely Hamilton, London, 1990; Pamela Hirsch, Barbara Leigh Smith Bodichon: Feminist, artist and rebel, London, 1998; Sally Mitchell, Frances Power Cobbe: Victorian feminist, journalist, reformer, Charlottesville, 2004. See also Dale Spender, Women of Ideas (and 
more on the specifically legal than others but all detail the campaigns and the efforts to gain public support through explaining, at meetings and in published writings, the substance and effect of the laws and what was wanted. What we need to do now is to link these biographies back into legal history and biography, from which they have routinely been omitted.

Ultimately, however, we need biographies of pioneering women in law not only to fill the gaps in legal scholars' understanding of the Victorian and Edwardian legal milieu, but also to change the existing story. It cannot be acceptable for legal biographies to perpetuate the exclusion of 'legal' women - those women who were subjects, objects, iconoclasts and reformers of law long before they were awarded the nomenclature of 'lawyer' - or to leave women out of our histories of the law society, the bar and the judiciary in these periods, given what we know about women's efforts to gain admission and the professions' long-standing opposition. ${ }^{70}$ Likewise, it cannot be acceptable to leave out of the biographies of legal men details of their participation in that opposition, or indeed (where relevant) their support. Women's exclusion from law-making is an important part of women's legal history. It is also an important part of men's.

\section{Feminist Legal Biography}

Despite the proliferation of studies of the lives of legal women, there has been little discussion of the content, method and purpose of feminist legal biography. What do we want from a study of individual lives in law? Is it enough simply to set down the 'facts', as far as we can find them, and outline the contribution to institutional legal history - or do we have more instrumental goals? Can a study of the past do more than simply describe what one person did in one historical context, or might it also be a useful tool in dealing with our current and future concerns? It is impossible to answer these questions - to consider the purpose of feminist legal biography - without also considering effect. The effect of traditional legal biographies that simply recount the subject's public achievements has been to perpetuate the disempowerment and subordination of women in law. They reinforce and

what men have done to them), London, 1982; Dale Spender, ed., Feminist Theorists, London, 1983; Caine, Victorian Feminists.

${ }^{70}$ See further Albie Sachs and Joan Hoff Wilson, Sexism and the Law, Oxford, 1984. 
justify women's continuing absence, as Miss Bebb found in 1914. ${ }^{71}$ Feminist legal biography, in contrast, aims not only to effect a more accurate and complete telling of all legal life stories, but to give both men and women a presence and a (not always comfortable) heritage that will help to explain why things were as they were and are as they are. Once we know our past, we are better armed to move forward. It goes without saying that women do need to move forward since, it is agreed, they still do not enjoy equality and justice in law. So how do we do this?

First we must recognize that feminist legal biography, like feminist legal history, ${ }^{72}$ is not just about women; rather, its focus is on gender: the relationship between men and women, ${ }^{73}$ however defined across time and place. ${ }^{74}$ It starts from the premise that gender is one of the main organizing principles in society (as Joan Wallach Scott points out, 'a primary way of signifying relationships of power') ${ }^{75}$ and that it affects everything we do. This was certainly the case in Victorian and Edwardian Britain, when their sex alone justified the different treatment of women in many aspects of legal, political and social life, and was responsible for women's exclusion from the legal profession. Other characteristics matter too; a person's class, race and sexuality have always been hugely important factors in a legal life, though usually only acknowledged in mainstream biographies if the subject is not a member of the white ruling class. Likewise, sex and gender are seen to be an issue only for a

${ }^{71}$ Where the court of appeal held that women could not be admitted as solicitors because there had never been any women solicitors: Bebb v Law Society [1914] 1 Ch. 286.

${ }^{72}$ Rackley and Auchmuty, 'The Case for Feminist Legal History'.

73 On the role of those who reject gender binaries in forming, contesting, and constructing feminist legal histories see, e.g., discussion of Radclyffe Hall's The Well of Loneliness in Caroline Derry, 'DPP v Jonathan Cape and Leopold Hill (1928)' in Rackley and Auchmuty, Women's Legal Landmarks, 205.

74 The use of gender as a category of (historical) analysis has been problematized, and we accept that gender is best understood as temporally, socially, culturally and political contingent; as Scott puts it, 'a historically and culturally specific attempt ... to assign fixed meaning to that which ultimately cannot be fixed' (Joan Wallach Scott, The Fantasy of Feminist History, Durham, NC, 2011, 5). See also Denise Riley, 'Am I That Name?' Feminism and the Category of 'Women' in History, Basingstoke, 1988.

75 Joan Wallach Scott, 'Gender: a useful category of historical analysis', 91 American Historical Review (1986), 1053 at 1069. 
biography of a woman. Since the norm is male in law, no need has been felt to discuss these categories in biographies of men.

But the fact that the British legal system was entirely male until 1919 needs to be explained, and can only be explained by reference to the systematic refusal of ruling-class men in the eighteenth and nineteenth centuries to allow women to be properly educated, to enjoy equality in law, to enter the professions, or to contemplate any career except a life of service of men. It is within this context that the biography of a Victorian woman or man might be positioned for it demonstrates the contrast between the male legal subject whose success is due in part to the fact that the doors were open to people like him and the female who, wanting a career in law (as significant numbers of Victorian women did), failed simply because those doors were closed to her.

More than this, the lives of all those eminent male jurists were smoothed not simply by the absence or marginalization of female competition but also by the presence of an army of female domestic support. Even after women were admitted to the profession, few of them enjoyed comparable support; ${ }^{76}$ in addition to the obstacles placed in their way at work and the relentless criticism they faced for departing from gendered norms, ${ }^{77}$ they had to manage households, possibly with (female) domestic assistance, but rarely with men's. Thus, in the twentieth century and beyond, a legal man's success stands in a direct relationship to a legal woman's struggles; he benefits from her burdens. Feminist legal biography therefore focuses on the relationship between men and women in both public and private spheres.

Here follow, therefore, some guidelines on how to approach feminist legal biography. We have identified three guiding principles: (1) women's issues are part of legal history; (2) the personal matters; and (3) heroines do not help.

\section{Women's issues are part of legal history}

One of the most obvious features of traditional legal biography is its neglect of women. This is not just a question of silence about a subject's private life; it is also exemplified by a failure to discuss, or even to mention, the public and legal changes affecting women during

\footnotetext{
76 Though see Hilary Heilbron's comment that 'A working mother's needs were no different 60 years ago from today' and discussion of her mother's 'help' which included variously a housekeeper, nanny, cook and cleaner (Heilbron, Rose Heilbron, 100).

${ }^{77}$ See, e.g., Heilbron, Rose Heilbron, 240-242; Helena Kennedy, Eve was Framed: Women and British Justice, London, 1992, 32-64.
} 
the subject's life. Women's legal status was almost completely transformed in the nineteenth century. But our survey of biographies of Victorian and Edwardian legal men revealed that very few referred to any legal developments concerning women at all, even when the subject of the biography was himself instrumental in bringing about the reform. ${ }^{78}$

For example, the entries in R F V Heuston's Lives of the Lord Chancellors 1885-1940 on Lord Buckmaster and Lord Finlay, opposing counsel in Bebb v Law Society [1914] Ch 286 and each pivotal to the women's many attempts and failures to gain entry to the legal profession, give no attention to the case or the issue it concerned. ${ }^{79}$ The banquet to celebrate the admission of women to the profession, which took place in the house of commons on 8 March 1920, was attended by (among others) Lord Reading (the lord chief justice) and Viscount Haldane ${ }^{80}$ but not only is this event not mentioned in the biographies we reviewed of these men, there is no discussion in any of them of the campaign for women's admission to the profession or of the Sex Disqualification (Removal) Act 1919 which finally admitted them. ${ }^{81}$ It is hard to imagine a more significant change to a profession than the admission of women, which called into question centuries of understandings about the nature of men and women and of public life. Yet it does not feature in any of these accounts.

Turning to other areas of legal reform, Trowbridge H Ford's Albert Venn Dicey: The Man and his Times says nothing about his support of women's legal education ${ }^{82}$ or his opposition to votes for women. ${ }^{83}$ John Hostettler's Lord Halsbury gives appropriate attention to the Clitheroe case, $R$ v Jackson [1891] 1 QB 671 - in which Lord Halsbury, Lord Esher and Fry LJ declared that no English subject had the right to imprison another person, even if

78 An exception is Edmund Heward's A Victorian Law Reformer: A Life of Lord Selborne, Chichester, 1998, which includes a chapter on 'Wives and Property' drawing on Lee Holcombe's feminist study Wives and Property: Reform of the Married Women's Property Law in Nineteenth-Century England, Toronto, 1983.

${ }^{79}$ R. F. V. Heuston, Lives of the Lord Chancellors 1885-1940, Oxford, 1964.

${ }^{80}$ Auchmuty, 'Whatever happened to Miss Bebb?' 224-225.

${ }^{81}$ Denis Judd, Lord Reading, London, 1982; Montgomery Hyde, Lord Reading: The life of Rufus Isaacs, first Marquess of Reading, New York, 1967; Jean Graham Hall and Douglas F. Martin, Haldane: Statesman, Lawyer, Philosopher, Chichester, 1996.

82 Auchmuty, 'Early Women Law Students', 82.

${ }^{83}$ Trowbridge H. Ford, Albert Venn Dicey: the Man and his Times, Chichester, 1985. 
she was his wife ${ }^{84}$ - but we learn nothing of his ferocious opposition to women's attempts to enter the legal profession. ${ }^{85}$ Jean Graham Hall and Douglas F Martin's Haldane: Statesman, Lawyer, Philosopher paints an interesting picture of Haldane's friendships with radicals and feminists, including suffragist Millicent Garrett Fawcett and pioneer doctor Elizabeth Garrett Anderson, but misses an opportunity to explore his contribution to reforms benefiting women, except for one surprising reference to his introduction of a bill for women's suffrage in $1889 .{ }^{86}$ We learn of his interest in the Working Men's College and the foundation of the London School of Economics, but not what his views on women's legal education were or their desire to enter the legal profession. Indeed, this otherwise comprehensive study is an excellent example of the 'now you see them, now you don't' genre of history-writing, in which women pop up here and there but there is no sustained narrative explaining their legal position or the subject of the biography's role in changing or maintaining it.

Are we to conclude then that women's entry into the legal academy and the legal profession, let alone to the franchise, is so unimportant to legal historians that these events do not merit inclusion in studies of men who were directly involved in them? Or is it rather that silence works better to suppress memories of the decades-long opposition by legal men to women's access to civil rights? After all, while it might have been possible to present the Sex Disqualification (Removal) Act 1919 as a natural progression in an increasingly civilized society, needing no further discussion, the decades of male opposition and hostility - let alone the embarrassing judgments in Bebb just five years earlier - would have been harder to explain away.

More likely is it that the biographers never gave it a thought. As Karen Tait suggests:

A charitable interpretation is that these men understood their personal stories as part of a larger history of government, law, and politics in an era of great social and economic change; unless a woman was a major player in an important legal reform or court battle - and few women were - there was no reason to mention her. ${ }^{87}$

${ }^{84}$ See Teresa Sutton, ' $R$ v Jackson (1891)', in Rackley and Auchmuty, Women's Legal Landmarks, 99.

85 John Hostettler Lord Halsbury, Chichester, 1998; Giles, The Disappearance of Miss Bebb.

${ }^{86}$ Hall and Martin, Haldane, 56-64.

${ }^{87}$ Karen M. Tait, 'Portia's Deal', 87 Chicago-Kent Law Review (2012), 549 at 550. 
For women, admission to the legal profession was an important legal reform and Bebb an important court battle. But if history remains the tale of men's achievements in the worlds in which they operate, and legal biography the stories of those men, the efforts of a small number of educated women to elbow their way into a profession hitherto barred to them will not be seen as part of that story, especially since women's participation is so completely taken for granted today. Put simply, men's issues count in legal history and women's still do not.

Legal biography remains fettered by this heritage. The first principle, therefore, of feminist legal biography is that women count. Women's issues count. Women's role in legal life, or their absence from it, counts. All these things need to be explored, as does the role of men in keeping them in that place, or out of it, or in helping women to gain a foothold in law or to effect legal change.

\section{The personal matters}

The second principle of feminist legal biography is that the personal is (always) present. Legal biography lags behind other biographical forms in its reluctance to embrace the relationship between the private persona and the public performance. It is striking how commonly biographers of legal men fall back on the Victorian format of a life lived wholly in public, with only marginal reference to private and, especially, gender concerns: men's relationship to women, and women's to men. Of course, a subject's wife and female relatives will be mentioned - there may even be an assessment of a mother, wife or lover's importance in his life $e^{88}$ - but there remains an almost Victorian resistance to delving any more deeply. Nicola Lacey's unusually detailed exploration of Herbert Hart's marriage and sexuality in $A$ Life of H. L. A. Hart: The Nightmare and the Noble Dream ${ }^{89}$ met with much criticism from scholars who thought these topics inappropriate in a legal biography. ${ }^{90}$

${ }^{88}$ E.g. Hall and Martin, Haldane, 10; Wilfrid E. Rumble, The Thought of John Austin: Jurisprudence, Colonial Reform, and the British Constitution, London, 1985, 15, 56-58; Edward Marjoribanks, The Great Defender: The Life and Times of Sir Edward Marshall Hall KC, England's Greatest Barrister, London, 1950, repr. London 2014, ch.4.

${ }^{89}$ Nicola Lacey, A Life of H. L. A. Hart: The Nightmare and the Noble Dream, Oxford, 2004. ${ }^{90}$ See, e.g., Thomas Nagel's comment that he felt 'I was learning too much that was none of my business': “"The Central Questions” - Review of Nicola Lacey’s A Life of H.L.A. Hart', 27 London Review of Books (2005). Lacey pre-empted this criticism in her introduction: 
Biographies of legal women have tended to have the opposite problem. Such studies will make more of the fact that they married and had children (or not) than biographies of men. One would like to imagine that this is because their authors recognize the second-wave feminist maxim that, for women, the personal is political, and that how we live our private lives profoundly affects our public lives. But we suspect that it is, rather, an acknowledgement that, because women are still identified with the private sphere, their family life really must be mentioned, if only to demonstrate that the woman under discussion was still successful in traditional terms (that is, for example, she found a husband, bore children, or - in Lady Hale's words, describing herself - was 'a home maker as well as a judge'). ${ }^{91}$ A less generous explanation might be the desire of some biographers to place their subject in a heterosexual context, or to insert men into the picture by discussing her relationship to her husband, especially if he can be shown in a good light.

A better reason for including a woman's private circumstances is that it raises the question of how she managed to combine career and family, an essential question to consider in a historical context that has always discouraged this. ${ }^{92}$ But all too often the question is just ignored or answered glibly, often drawing on the subject's own un-interrogated assertion that her husband was 'supportive' or that he 'helped with' the housework or children. ${ }^{93}$ Such a statement makes it abundantly clear that housework and childcare are really women's responsibility (one reason why they are never discussed in biographies of men) and is in turn is revealing of the domestic challenges (still) facing women trying to make a legal career, quite apart from the challenges they face in the professional world itself. Husbands aside, having the means to pay for childcare and domestic help - the availability of creches, family-

'Though some readers may feel that I have been too generous in my use of the personal material - particularly that relating to his feelings about his sexuality and his marriage - my judgement was that it was essential to any interpretation of him as a whole person' (xix-xx).

${ }^{91}$ Formerly on the biographies of the supreme court site: www.supremecourt.uk > about $)$ biographies-of-the-justices.

${ }^{92}$ See, e.g., Catherine Baksi, 'A good lawyer or a good mother? Women still face a tough decision', The Times, 7 March 2019.

${ }^{93}$ It is striking how many contributors to the international collection on Gender and Careers in the Legal Academy (Ulrike Schultz, Gisela Shaw, Margaret Thornton and Rosemary Auchmuty eds., London, forthcoming) deal with this point in this way. 
friendly work practices, employer attitudes - have all played, and continue to play, a role in determining the course of a legal woman's life. Meanwhile, the professional woman who has not married or had children is inevitably depicted as an exception at best, a failure (in human terms) at worst. No such judgement attends a man.

While it is self-evident then that a women's private life will be relevant to an account of her public life, it is less evident, perhaps, that a man's might be relevant to his. Yet of course it is. Women have almost always played a significant material role in men's lives (and where they have not, that is also worth discussion), and most men in public life simply would not have achieved what they did without the support structure supplied by women in some way or other. This fact of life is generally taken for granted in biographies of legal men on the basis that the role of women in a great man's life is naturally a supportive one. In fact, it is central. To enable men to succeed in public life, countless women just as able, or even more so, have had to fail - and that is another reason why there are so few legal biographies of women.

\section{Heroines do not help}

A third principle of feminist legal biography is that - despite the apparent omnipresence of 'role models', 'icons', 'pioneers' - it is not about creating heroines. That it not to say it is not about uncovering the lives of women missing from legal history. At the start of the twentyfirst century, while quite a lot had been written about votes for women, there was almost no information in the public domain about women's efforts to join the legal profession; indeed, the names of the first woman law student, law graduate, solicitor and barrister were simply unknown and had to be ferreted out by assiduous researchers. Thanks to their efforts, we now know a great deal more about the early women lawyers. The value of this work has been inestimable. But it seems to have been almost impossible for many of the compilers of these new life stories to avoid the temptation to cast their narratives in traditional modes of women's biography, as heroines or role models, all the more so because the underlying mission for so many of them has been to find those very heroines and role models for the ever-increasing number of girls and young women aspiring to become lawyers. ${ }^{94}$

\footnotetext{
${ }^{94}$ By way of example: '[The book] portrays a multi-dimensional picture of the young and beautiful Rose Heilbron - barrister, judge, working wife and mother - who not only managed to combine these public and private roles in an era when to do so was extremely rare, but who did so with the combination of warmth, flair and determination which was to make her an
} 
In the nineteenth century we had 'noble' and 'good' women. Today we have them once again, under a different name. The stories of inspirational women are still a regular fixture on the non-fiction shelves of children's libraries. Recent collections such as the Fantastically Great Women Who Changed the World or who Made History or Good Night Stories for Rebel Girls tell the stories of these 'exceptional' women; women who 'follow[ed] their hearts, talents and dreams' and ended up making some important contribution to 'mankind' ${ }^{95}$ Like the narratives of more traditional fairy tales, their familiar yet different characters and predictable plotlines span time-zones and cultures. And as with these tales, their narratives follow a formulaic structure designed, in this case, to overcome the challenge of honouring women who did something they were not supposed to do: that is, step outside the conventional realm of women, the private sphere, into the public sphere which belonged to men, and succeed in spite of all opposition.

Heroine narratives can be identified by the following features. Step one: the woman or girl has to be appropriately feminine, in spite of her apparently masculine career, so that she is acceptable in the one world before she enters the other. Step two: some reason has to be found for her entry into public life. This could be the death of an actual - or potential husband, ${ }^{96}$ falling on hard times, or her father lacking a son. Or it could be excused if the woman's work was opening up a new area of service for women, like Florence Nightingale's nursing. ${ }^{97}$ Step three: the inevitable opposition of men is minimized or relegated to the past

internationally acclaimed role model for women' [our emphasis] (Heilbron, Rose Heilbron, cover statement).

${ }^{95}$ Kate Pankhurst, Fantastically Great Women Who Changed the World, London, 2016, and Fantastically Great Women Who Made History, London, 2018; Elena Favilli and Francesca Cavallio eds., Good Night Stories for Rebel Girls: 100 Tales of Extraordinary Women, London, 2017.

96 For example, Pankhurst writes: 'In secret letters to her sister, Jane [Austen] writes of having her own heart broken, just like the heroines she wrote about, by a man called Tom Lefroy. The two weren't allowed to marry because Jane's family was not rich. With no husband, Jane had to rely on her family for money, until her books became popular!' (Pankhurst, Fantastically Great Women Who Changed the World, 23-24.)

97 'The nurses [who had travelled with Nightingale to the Crimea] had proved that the people in England were wrong who doubted whether they were suitable for nursing wounded soldiers in war. From that day women nurses have always been part of the Army, and in two 
('it was like that then'), and the role of male mentors emphasized, indeed exaggerated, to show that most men were basically fair (and, indeed, that their assistance was essential to the women's success). And finally, step four: there is a rigorous selection process to be undergone before a woman might have 'great woman' or 'heroine' status conferred upon her. Women whose lives cannot be normalized, feminized or heterosexualized ${ }^{98}$ must be excluded.

The problem is that many of the recent potted biographies follow a similar structure to the children's tales - 'she strove, and she got there' - a structure that focuses on the struggles and challenges of women's fight to become lawyers, their eventual success, and lessons for future generations. What this means is that the resulting narratives do not produce a real or complete story. Rather, they offer (over-simplified) versions of women's lives that can be harnessed for a political purpose: what Helena Kennedy has called 'tent pegs which secure the status quo'.99 Women who succeed do so on men's terms. They are absorbed into patriarchal society rather than transforming it. And should a young reader aspire to be a great woman too, or even just a successful professional, these stories will provide her with parameters within which she must shape and contain her aspirations: guidelines which may be repugnant, and often impossible, for the aspirant to follow, or which, when followed, still do not produce the desired result.

Despite (as Mary Jane Mossman notes) the ongoing inequalities within the legal profession meaning that 'the experiences of nineteenth-century women lawyers often seem quite contemporary, ${ }^{100}$ stories where women succeed at all costs are of little help to a later generation in a different context. Few of us are as advantaged as Florence Nightingale and most of the early women lawyers and judges. Class, race, education and family and social connections have all played a role in women's (and men's) ability to negotiate the arcane structures of the legal profession. Moreover, the challenges young women face today are not the same as those they faced. However important it is to show girls that women can succeed and to encourage them, thoughtless narratives of achievement do nothing to help young

world wars many thousands of wounded soldiers have owed their lives to them' (L. Du Garde Peach, Florence Nightingale, London, 1959, 36).

${ }^{98}$ See the introduction to Lesbian History Group, Not a Passing Phase: Reclaiming Lesbians in History, London, 1989.

${ }^{99}$ Kennedy, Eve Was Framed, 32.

100 Mossman, The First Women Lawyers, 288. 
women seeking to achieve greatness in law. They are more likely to engender disappointment, self-doubt and a sense of powerlessness when hopes are dashed and the obstacles prove too great.

Simply for this reason, the very notion of setting up an individual woman as a heroine is unhelpful. But there are other objections. First, this characterization tends to isolate the person, and to suggest that she acted alone rather than as a part of a much wider group pressing for reform. Early studies of Victorian feminism tended to adopt the 'great man' approach in their portrayal of feminist leaders. 'The importance of individual women and of their achievements was once taken as the starting point in writing the history of feminism,' notes Barbara Caine, citing Ray Strachey's The Cause: A Short History of the Women's Movement in Great Britain ${ }^{101}$ as an example of 'a heroic story of the ways in which the obstacles to women's emancipation were removed by a series of successful campaigns, each led by a notable individual'. ${ }^{102}$ As Hilda Kean points out, this approach was strategic, undertaken in order to reclaim the reputations of feminists who had only recently been viewed as dangerous revolutionaries. ${ }^{103}$ First-wave feminists drew on traditional characterizations when re-telling their own life stories, depicting themselves as martyrs and pioneers: Mary Richardson, the woman who slashed the Rokeby Venus in the National Gallery to gain publicity for votes for women, declared in her autobiography: 'We shall be remembered as women who opened the door to complete freedom'. ${ }^{104}$ It is testament to the success of masculine scholarship in obliterating all knowledge of these legal activists that most of these women, including Mary Richardson, are not remembered at all.

In contrast, perhaps the greatest distinguishing feature of recent feminist biography has been its insistence on locating individual women within networks of family, friends and

${ }^{101}$ Ray Strachey, The Cause: A Short History of the Women's Movement in Great Britain, London, 1928; repr. London, 1978. Ray Strachey was the chair of the committee to obtain the opening of the legal profession to women, and hosted the celebratory banquet in the house of commons in 1920.

102 Barbara Caine, 'Feminist biography and feminist history', 3 Women's History Review (1994), 249.

${ }^{103}$ Hilda Kean, 'Searching for the Past in Present Defeat: The construction of historical and political identity in British feminism in the 1920s and 1930s', 3 Women's History Review (1994), 60.

${ }^{104}$ Mary Richardson, Laugh a Defiance, London, 1953, 104, quoted in Kean, ibid. 
political allies, all the better to illuminate both the private and public dimensions of their lives. We know that feminists rarely operate alone: Miss Bebb, for example, was but one actor in a long and widely supported campaign to get women into the legal profession. We do not know why she was chosen to be plaintiff in the test case to which she gave her name but we do know that she was only one in a group of eligible young women who were in turn supported by a movement that had been active for fifty years. Entry into the profession would not and could not have been achieved through the work of a single person but, if you reduce the struggle to individual effort, you give later generations the idea that they too can succeed on their own and you discourage them from forming alliances which are not only more effective, but also more threatening to the status quo. And you suggest that the reform was won by the efforts of your heroine whereas in reality it took generations of struggle before her and probably after as well.

A second problem with the heroine model, as feminists have long realized, is that it is all too easy for someone we have put on a pedestal to be knocked down from it. Mary Wollstonecraft is an early example of this process, when not only Victorian society generally but even many feminists condemned her for bearing a child out of wedlock and refusing to marry. ${ }^{105}$ It is for this reason that the organizers of the Greenham Common demonstrations in the 1980s, when women occupied an American military base to protest against bringing nuclear weapons to Britain, were careful to have no leaders. A mass movement, they knew, is much harder to demolish. There were no heroines of Greenham Common, but the women succeeded in keeping nuclear weapons out of Britain. ${ }^{106}$

A further problem is that heroines can prove disappointing. We expect that heroines will help others coming up after them. It is as wrong, however, to assume that all successful women will be role models for young women to follow, as it is for a biographer to castigate them for not being so without a full investigation of their situation. There may be good reasons, or bad ones, why a woman disclaims the title of 'feminist' or refuses to work with other women: it is the biographer's task to find them. Barbara Babcock, faced with a subject who was not a model heroine (Clara Foltz, California's first woman lawyer), chose to 'mix

105 See Millicent Garrett Fawcett's introduction to the centenary edition of Mary Wollstonecraft, A Vindication of the Rights of Woman, London, 1897, reprinted 2015.

106 See Elizabeth Woodcraft, 'Greenham Common Women's Peace Camp, 1981-2000' in Rackley and Auchmuty, Women's Legal Landmarks, 366. 
the hag with the hagiography'. ${ }^{107}$ It was a technique that worked brilliantly as her subject emerges as someone who, like real women, sometimes made mistakes, took wrong turnings, and was forced into compromise, yet ended up achieving astonishing things.

Finally, it is often assumed that, once the heroine has pushed her way through the barrier, things will be fine for women from then on. This is rarely the case. What legal history and biography show us is that there is almost always a backlash - a token woman or a few might be fine, but to avoid an influx rules may be changed (as happened when women tried to enter the medical profession), ${ }^{108}$ or discrimination becomes covert rather than overt (for example, when the dearth of women in the judiciary is explained away as the result of their not being good enough). ${ }^{109}$

\section{Three pitfalls to avoid}

As a model of doing and presenting legal biography, then, the 'great woman (lawyer)' narrative is not without significant pitfalls. We focus here on three. The first - overfamiliarity - encourages the biographer to believe that she 'knows' her subject, that she learnt so much about her she can truly empathize with her position, understand her actions and predict her responses because they chime with her own experiences. Conscious or otherwise, these narratives usually adopt the same 'tell': the use of the woman's first name. Scholars who would never write about 'John' for John Stuart Mill or 'Tom' for Lord Denning do not hesitate to refer to 'Helena', 'Rose', 'Carrie', or 'Gwyneth'. ${ }^{110}$ Suparna Gooptu, for example, explained that she called the subject of her biography of Cornelia Sorabji 'Cornelia' throughout the book because she felt by the end of her research she had come to know her as a friend. ${ }^{111}$ Refraining for doing this is not simply a matter of politeness or etiquette, though many of these women would never have been referred to by their first names by any but their

\footnotetext{
${ }^{107}$ Babcock, Woman Lawyer: The trials of Clara Foltz, $\mathrm{x}$.

${ }^{108}$ E. Moberly Bell, Storming the Citadel, London, 1953.

${ }^{109}$ Erika Rackley, 'So Butler-Sloss, our women and ethnic minority lawyers aren't up to the job?’ The Guardian, 31 May 2012.

${ }^{110}$ Second-wave feminists also saw in this insistence of referring to women by their first names a process of infantilizing women, treating them like children.

111 Suparna Gooptu, Cornelia Sorabji: India's Pioneer Woman Lawyer: A biography, Oxford, 2010, x.
} 
family and closest friends. It is rather that it suggests that the author is at risk of encountering a second pitfall: anachronism and historical inaccuracy.

Whenever we write about someone else, however much we know (or think we know), however much our subjects have told us directly (through interviews or autobiographies) or indirectly (through diaries and letters, or other people's recollections of them), we can never fully understand what their life was like for them. We can only do our best to assess the evidence, and hypothesize. Especially when writing about remarkable women - whether contemporary or historical - we cannot claim to 'know' how our subject would have thought or acted, why they did or did not do something, just because we know how we would have thought and acted (or think we do), even if we are a member of the same profession or quite remarkable ourselves. They lived in different times. All we can do is to conjecture as to our subjects' attitudes or reasons based on our knowledge of their historical context and our understanding of women's position in society and law, garnered from as extensive a range of sources as possible. A wide sweep, which might include fiction, biographies and autobiographies of contemporaries, even case law, is almost always going to be necessary when undertaking biographies of women, who have generally left very few records. ${ }^{112} \mathrm{We}$ must present a narrative that is as informed as possible, but which embraces its incompleteness and does not set itself up as 'truth'.

The third pitfall is the siren call of anecdote and myth. Anecdotes can be wonderfully useful ingredients in a biography for adding colour and bringing the person 'alive'. It is through these stories that we begin not only to understand their subject and how they (and women generally) were viewed by their contemporaries, but to make links with the tales of others. Hilary Heilbron's biography of Britain's first woman judge, her mother, Rose Heilbron, is illuminated throughout by stories of events and behaviour, some of which only someone as close to her subject as she was could recount. At once familiar and peculiar, these tales act as catalysts connecting the individual women to their past, present and future, and to ours. $^{113}$

It is all too easy, however, to confuse myth with anecdote. Heroine stories encourage the creation of myth and we need to be particularly vigilant in checking our sources in doing this kind of work. If a story appears once, it is repeated and repeated until it acquires the aura

\footnotetext{
112 Auchmuty, 'Recovering Lost Lives', 36.

${ }^{113}$ Erika Rackley, 'Judicial Diversity, the Woman Judge and Fairy Tale Endings', 27 Legal Studies (2007), 74.
} 
of truth, even though there is no original source given and no discernible evidence for it. Like the folk tales retold by the Brothers Grimm, the stories of 'Miss Bebb', Helena Normanton, Lady Hale and others have become part of our collective narrative; stories we tell - and elaborate - for whatever purposes we desire: to make connections, to celebrate our successes and (sometimes) to suggest that we know more than we do. And just as the Brothers Grimm collated folktales from across Europe, including those of Charles Perrault published 100 years earlier (who was, in turn, giving a 'modern twist' to half-forgotten folk tales), in the rush to suggest a familiarity with 'Gwyneth', 'Helena', 'Brenda' - to tell their version of the fairy tale - years of painstaking archival work by those both within and outside the academy, building connections with surviving family members, and sifting through evidence in order to find and tell the now familiar stories, may be trampled over, distorted or ignored, and the stories that remain are as much myth as the Victorian tales of noble women.

For the feminist legal biographer, this is not simply a matter of checking our sources, and not repeating falsehoods or half-truths, the disingenuous or salacious. ${ }^{114} \mathrm{We}$ also have a responsibility not to become bewitched by the story. As with the childhood tales of talking animals, dragons and mermaids, and of 'great' or 'fantastic' women, to stay with the story of the anecdote or myth is to misunderstand its purpose. It is not the story itself that is important, but rather where that story takes us; the extent to which - like all fairy tales and myths - it offers 'the possibility of change, far beyond the boundaries of their improbable plots or fantastically illustrated pages' and opens windows on to ways forward. ${ }^{115}$ Told well, these stories not only allow us to walk in the shoes of others - to acknowledge 'the real battles that took place to get women where they are today' ${ }^{116}$ - but, by throwing light on to new ways forward, they also challenge complacency and the assumption, as noted by Lady Hale, 'that just because some things have changed, the struggle for equality is over'. ${ }^{117}$

${ }^{114}$ Too many recent versions of women's legal lives contain no references, so that accuracy cannot be checked and information followed up, or even acknowledgement of the work they have drawn upon. Perhaps it is the internet which has made all knowledge common property. 115 Marina Warner, From the Beast to the Blonde: On Fairy Tales and their Tellers, London, 1995, xii.

116 Sandra Day O'Connor, 'The Majesty of the Law', Interview for Online News Hour, 9 June 2003.

${ }^{117}$ Brenda Hale interviewed in Elizabeth Cruickshank, ed., Women in the Law: Strategic Career Management, London, 2003, 135. 


\section{Conclusion}

This article has outlined the principles of feminist legal biography and offered a justification - indeed an exhortation - for its adoption as not only a more complete and more accurate representation of what it was like for a given biographical subject but also a fairer assessment of his or her contribution to legal history. It has argued that neither traditional legal biography nor women's legal biography shorn of feminist method is sufficient to give a real insight into the journey that has brought women from total exclusion from the professions of law to their present status as majority entrants into those professions To understand not only the role that women played but the role that men played (and still play) in excluding women from the work of the law requires us not merely to capture the life stories of women lawyers, but to apply a feminist analysis to biographies of women and men. We need the outputs of feminist legal history, of course, but we also need biography: first, because so much of the energy devoted in recent years to uncovering women's forgotten legal history has been focused on finding and naming our pioneers, and, second, because individual lives have wide appeal. There is pleasure, as well as insight, in getting inside another person, in seeing them in their context, rather than simply exploring the wider canvas. Too often that wider canvas has excluded or minimized the part played by women, so we need those individual lives of women to populate it. Too often it has excluded or minimized the part played by men in keeping women out, so we need a feminist approach to those individual lives of men to get the full picture.

The more that is known about the gendered context in which the subjects of legal biography existed, the clearer will be our readers' understanding of the situation in which they find themselves today and the better their preparedness for the challenges they still face - not because history repeats itself, but through gaining insight into the mechanisms that work to perpetuate a status quo that has always favoured men. Feminist legal biography is a tool in women's empowerment, but it also serves the cause of truth. It is everyone's responsibility to get it right.

\section{Note on Contributors}

Rosemary Auchmuty and Erika Rackley are professors of law at the Universities of Reading and Kent respectively. Together they led the Women's Legal Landmarks Project, a unique 
interdisciplinary collaboration involving over eighty feminist scholars from law, history, and other disciplinary backgrounds, activists, practising lawyers and judges in identifying, researching and producing critical accounts of ninety-three key legal 'landmarks' (events, appointments, cases and statutes) for women in the UK and Ireland. You can read more about the project via the Project's website: www.womenslegallandmarks.com and on Twitter: @wlegallandmarks. 